\title{
STUDY OF MECHANICAL PROPERTIES OF NATURAL FIBRE COMPOSITE
}

\author{
Rajendra Prasad Verma, Vinod Kumar Verma and Ajeet Kumar Rai \\ Department of Mechanical Engineering, \\ Shepherd School of Engineering and Technology, \\ Sam Higginbottom Institute of Agriculture Technology and Sciences, \\ Deemed University Allahabad (U.P.) INDIA.
}

\begin{abstract}
In the present work an attempt has been made to fabricate a natural fibre reinforced plastic composite using sisal and jute fibres. $20 \%$ sisal, $10 \%$ jute, $10 \%$ starch, 40\% epoxy (araldite AY-103) and 20\% hardener is used to fabricated FRP composite. The composite is fabricated by simple hand lay method. Mechanical properties are tested and found satisfactory. Water absorption test of the composite is tested as per ASTM standard. It is observed that material is light in weight with sufficient strength and of low cost which make it suitable for many engineering applications.
\end{abstract}

Key words: Composite materials, Fiber Reinforced Composite.

Cite this Article: Rajendra Prasad Verma, Vinod Kumar Verma and Ajeet Kumar Rai, Study of Mechanical Properties of Natural Fibre Composite. International Journal of Design and Manufacturing Technology 7(1), 2016, pp. 01-06.

https://iaeme.com/Home/issue/IJDMT?Volume=7\&Issue=1

\section{INTRODUCTION}

Composite materials are consisting of two or more chemically distinct constitutes, on a macro-scale having a distinct interface separating them. Hybrid composite materials are which are made by combining two or more different types of fibers in a common matrix.

Sisal and jute is an important fiber plant in Asia. It has been cultivated since ancient times and there are no known wild ancestors. It is a shrubby annual legume from 3-5 ft. tall with bright yellow flowers. It is grown primarily in southern India. Sisal is an attractive natural fiber for use as reinforcement in composite because of its low cost, renewable nature and much lower energy requirement for processing. It is a long, soft, shiny vegetable fiber that can be spun into coarse, strong threads. Its botanical name is agave sisalnama. It is mostly produced in India, Bangladesh and China. Fibers come from the stem and ribbon (outer skin) of the sisal plant. This has 
prepared for harvesting are their fibers bundle of fibers and sisal yarns. Poor resistance against moisture, brittles under influence of light, absorbs paint easily. Sisal consists of very short elementary fibers (length 0.7-6 mm) which are stuck together by lignin to form long brittle fibers. U. S. Ishiaku et al. have studied fabrication and characterization of the mechanical and morphological properties of short fiber reinforced sisal/poly butylene succinate (PBS) biodegradable composites in 2005. The effect of a dual gated mould in the fabrication of welded specimens was a key focus of the investigation. It was observed that incorporation of sisal fiber conferred drastic changes on the stress-strain properties of the matrix as the elongation at break (EB), dropped from $160 \%$ in the matrix to sisal $20 \%$ in the composite. The tensile strength of the composite was lower than that of the matrix. However, it is noteworthy that the tensile modulus of the composite increased. Bending test also revealed that both bending strength and modulus increased with the incorporation of sisal. Morphological studies of the tensile fracture surface using SEM revealed two types of failure mode.

\section{MATERIALS AND METHODS}

A 20\% Sisal, $10 \%$ jute, 10\% starch, 40\% epoxy (araldite AY-103) and $20 \%$ hardner is prepared by using hand lay-up technique. For this purpose, an open mould made of mild steel plate $(600 \mathrm{~mm}$ long $\times 300 \mathrm{~mm}$ wide $\times 27 \mathrm{~mm}$ thick $)$ has been used. . Firstly, a Mylar sheet is placed on the lower part of mould for a good surface finish and easy withdrawal of bio-composite from the mould in addition to it wax is also used to cover the surface of Mylar Sheet for easy withdrawal of bio-composite from Mylar sheet. Sisal fibers placed unidirectional on it. Then the matrix (mixture of $20 \%$ sisal and 40\% epoxy and 20\%hardner) has been layered on the mould (3 mm) thickness. After removing the entrapped air with the help of metal roller rolled on the layer, thereafter layer of matrix has been poured on the mould. Then upper part of mould is placed on side plates, which placed on both side of lower part of mould. In this way to cast the specimen of the bio-composite sheet produced single ply having thickness between $8 \mathrm{~mm}$ and then left for 48 hours for curing at room temperature $\left(16-29^{\circ} \mathrm{C}\right)$. After 48 hours it is removed from the mould. Then this sheet is used to make compressive test specimens according to ASTM Standards. Taking out fabricated sheet of bio-composite from the mould and fabricated sheet of biocomposite. Compression test and impact test specimens are required higher thickness, so closed wooden moulds have been used, in which the mould that has been used to make tensile test specimens has different length, height and width. The internal surface of mould is covered with Mylar sheet with wax covered over Mylar sheet to protect matrix piece to stick with Mylar sheet. Then the matrix has been layered on lower part of the mould $(40 \mathrm{~mm})$ thickness and a layer of sisal fibers placed unidirectional on it. After layer of Sisal fibers again matrix layer is applied. Then upper part of mould is placed on lower part of mould and then left for 48 hours for curing at room temperature $\left(16-29^{\circ} \mathrm{C}\right)$. After 48 hours it is removed from the mould. Then tensile test specimens of required dimensions according to ASTM Standards are cut from the fabricated sheet of bio-composite. 
Study of Mechanical Properties of Natural Fibre Composite

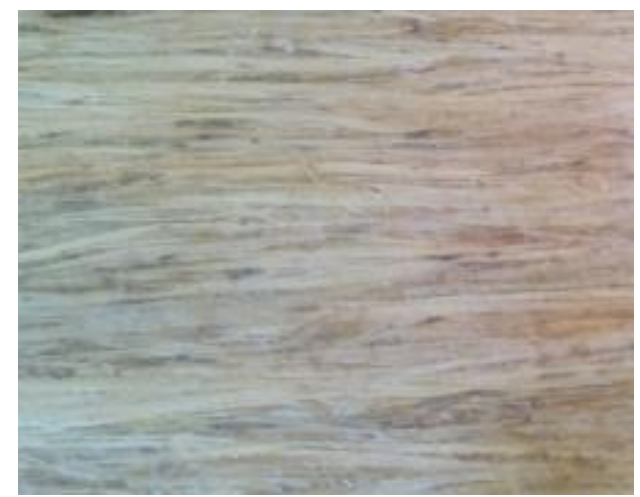

Processed fiber composite material

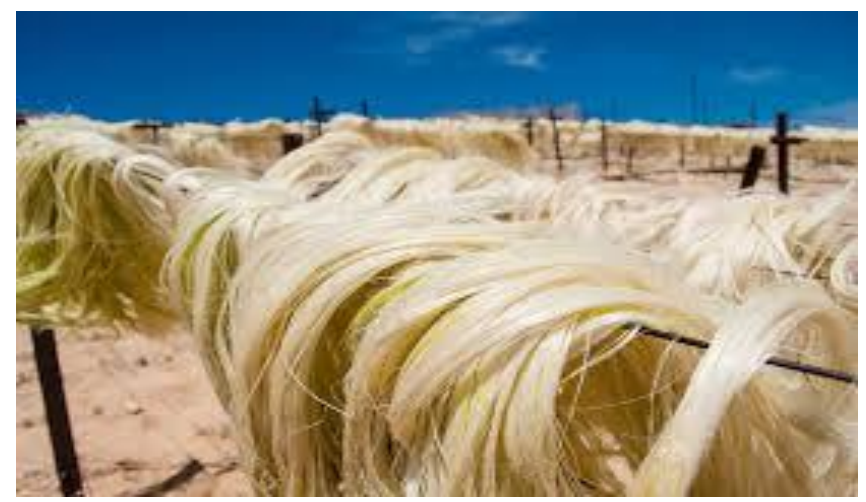

Sisal raw material

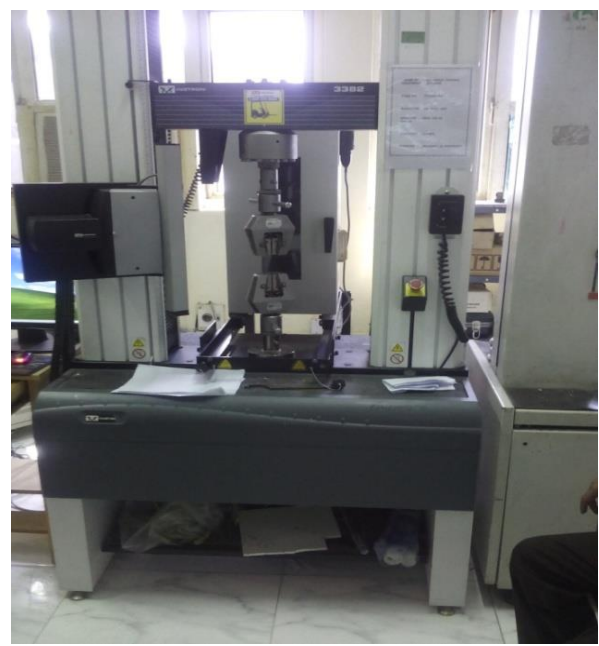

UTM Machine

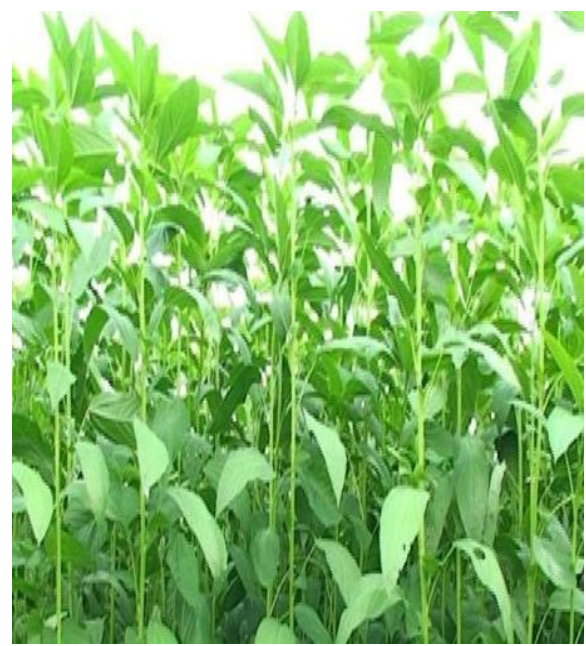

Jute plant 


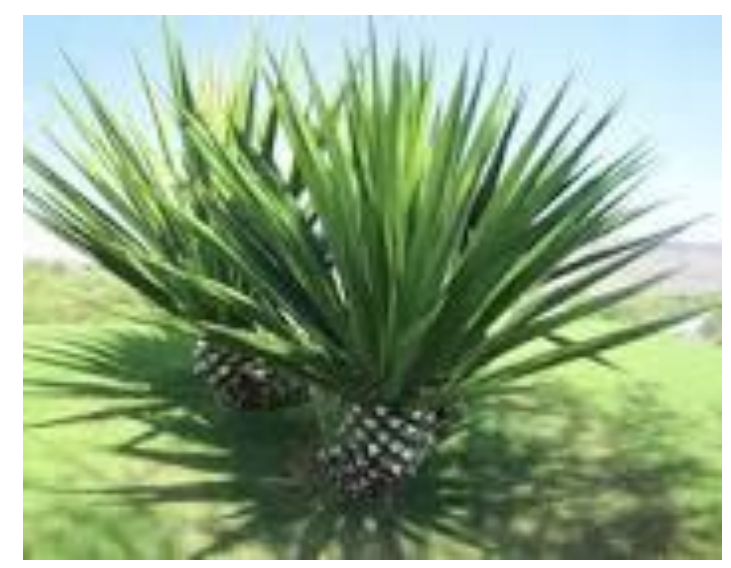

Sisal Plant

Figure 1 Photographs of the fibers and the plants

The application of natural and manmade fibers reinforced bio composite materials are growing day by day in every field of engineering due to its characteristics like eco-friendly, recyclable, bio-degradable and user friendly in nature. Many researchers are working in this field to make the sisal composites and to replace metals and alloy materials in the field of engineering and technology without affecting the load carrying capabilities and cost aspects. In the present experimental study, the sisal composite laminates. Then the test specimen are prepared from the composite laminates as per ASTM standards and testing of materials has been carried out under tensile, flexural and impact loading conditions by using universal testing Specimen fracture Specimen fracture Notch machine and impact testing machine. The experimental results on mechanical properties of the tested composite.

\section{RESULTS AND DISCUSSIONS}

The UTM was fully calibrated on the time of testing.

Table 1 For flexural test

\begin{tabular}{|c|c|c|c|c|c|c|}
\hline S.N0. & Width(mm) & Thickness(mm) & $\begin{array}{c}\text { Supported } \\
\text { Spam(mm) }\end{array}$ & $\begin{array}{c}\text { Maximum } \\
\text { Load (N) }\end{array}$ & $\begin{array}{c}\text { Flexural } \\
\text { strength(MPa) }\end{array}$ & $\begin{array}{c}\text { Elongation } \\
(\mathbf{\%})\end{array}$ \\
\hline 1 & 16 & 14.60 & 95 & 940.59 & 39.386 & 3.42 \\
\hline 2 & 16 & 14.60 & 95 & 961.20 & 40.16 & 3.80 \\
\hline 3 & 16 & 14.60 & 95 & 938.62 & 39.22 & 3.36 \\
\hline
\end{tabular}

The UTM was fully calibrated on the time of testing.

Table 2 For compressive test

\begin{tabular}{|c|c|c|c|c|c|}
\hline S.NO & Thickness(mm) & Width(mm) & Area $\left(\mathbf{m m}^{\mathbf{2}}\right)$ & Load(N) & $\begin{array}{c}\text { Compressive } \\
\text { Strength }\left(\mathbf{N} / \mathbf{m m}^{\mathbf{2}}\right)\end{array}$ \\
\hline 1 & 28.10 & 24.74 & 695.20 & 21393.85 & 30.77 \\
\hline 2 & 28.10 & 24.74 & 695.20 & 22001.72 & 31.69 \\
\hline 3 & 28.10 & 24.74 & 695.20 & 21200.15 & 30.49 \\
\hline
\end{tabular}




\section{Shore -D Hardness Test Bio-Composites}

Hardness Test (Shore D)

Test method ASTM D 2240

Test value obtained: 69

\section{Water Absorption Test of Bio-Composites}

Water Absorption Test

Test method ASTM D 570

Test value obtained: $1.7 \%$

\section{CONCLUSION}

Successful fabrication of the hybrid composite using sisal fibre reinforced composite was done by hand layup technique. Tests were performed according to ASTM standard to find the compressive and flexural strength of the material. Compressive strength of $31 \mathrm{MPa}$, and flexural strength of $39.56 \mathrm{MPa}$ are obtained. Shore D test is performed according to ASTM D 2240 to find its hardness, which comes out to be 69 unit. Material is tested for water absorption properties according to ASTM D 570, and the result is obtained as $1.7 \%$.

The soaking time for the present chemical composition yields the very good flexural properties which are evidenced from the experimental results. This work also demonstrates the potential of the hybrid natural fiber composites can be regarded as a useful material in light weight applications. Value of mechanical parameter of potato starch where found to be strongly influenced by moisture content of the material and amount of lubricant added.

\section{APPLICATIONS}

The bio-composites fabricated in this research work i.e. the sisal fiber based biocomposites has some applications are given as follows:

1. Building and construction industry: panels for partition and false ceiling, partition board, wall, floor, window and door frames, roof tiles, mobile or prfabricated buildings which can be used in times of natural calamities such as floods, cyclones, earthquakes, etc.

2. Furniture: chair, table, bath units.

3. Bio-degradable Packagings.

4. Everyday application: suitcases, helmets, etc.

5. Sports Things (e.g. rackets, nets, etc.).

6. Transportation: automobile and railway coach interior, boat, etc

\section{FUTURE SCOPE OF THE WORK}

1. For different temperatures, characteristics of bio-composites can be analyzed.

2. Wheat, rice husk, wheat starch, corn starch, soy protein, etc. can be used in fabrication of bio-composites.

3. Thermal characteristics of bio-composites can be analyzed.

4. Research should be done with for sisal fiber reinforced biodegradable composites so that a fully biodegradable material (green composite) may be 
fabricated which can be used in packaging and home appliances. It will also be good for eco-friendly environment.

\section{REFERENCES}

[1] Pruttipong Pantamanatsopaa, Warunee riyawiriyanana, Tawatchai, Meekeawa, Rattiyakorn Suthamyonga, Ketsara Arruba and Hiroyuki Hamadab, Effect of Modified Jute Fiber on Mechanical Properties of Green Rubber Composite, Energy Procedia 56 ( 2014 ) 641 - 647.

[2] U. S. Ishiaku, O. A. Khondker, S. Baba, A. Nakai and H. Hamada, Processing and Characterization of Short- Fiber Reinforced sisal/Poly Butylene Succinate Biodegradable Composites: The Effect of Weld-Line, Journal of Polymers and the Environment, 13(2), April 2005, DOI: 10.1007/s10924-005-2946-8, 2005.

Natural rubber latex-Wikipedia, the free Encyclopaedia, http://en.wikipedia.org/wiki/ natural fiber latex

[3] E. A. Bondareva, N. V. Sirotinkin, Yu. V. Omel'chuk, and M. G. Davudov, Relationship between the Strengths of the Composite and Binder, Russian Journal of Applied Chemistry, 82(9), pp. 1620-1623, 2009.

[4] S. Balasubramanian, Anjan Borah, K. K. Singh and R. T. Patil, Rheological and nutritional quality of selected dehulled legumes blended sisal extrudates, J Food SciTechnol, DOI 10.1007/s13197-010-0206-y, 2011.

[5] Nesibe gozde ozerkan, Bappy ahsan, Said mansour, Srinath R.lyengar, Mechanical performance and durability of treated palm fiber reinforced mortars, International Journal of sustainable built environment (2013)2.131-142.

[6] J. Prachayawarakorn, N. Limsiriwong, R. Kongjindamunee and S. Surakit, Effect of Agar and Cotton Fiber on Properties of Thermoplastic Waxy Rice Starch Composites, J Polym Environ, DOI 10.1007/s10924-0110371-8, 2011.

[7] Sukhdeep Singha, Dharmpal Deepakb, Lakshya Aggarwalc, V.K. Guptab, Tensile and flexural behavior of hemp fiber reinforced virginrecycled HDPE matrix composites, Procedia Materials Science 6 (2014) 1696 1702 .

[8] Sadhana, Ajeet Kumar Rai, Vivek Sachan and Maheep Kumar. Experimental Study on A Finned Basin Solar Still. International Journal of Mechanical Engineering and Technology 6(7), 2016, pp. 16-20.

[9] Ajeet Kumar Rai, Amit Kumar, Pravin Kumar and Ayaj Ahamad Ansari. Experimental Study on A Domestic Refrigerator Using LPG as A Refrigerant. International Journal of Mechanical Engineering and Technology 6(11), 2016, pp. 43 - 49.

[10] Ajeet Kumar Rai, Vivek Sachan and Bhawani Nandan. Experimental Study of Evaporation in A Tubular Solar Still. International Journal of Mechanical Engineering and Technology 4(2), 2013, pp. 01-09. 